\title{
A New Host of Clavella alata Brian, 1909 (Siphonostomatoida; Lernaeopodidae) from Turkish Seas
}

Ali Alaş ${ }^{*}$,

Ahmet Öktener²,

Dilek Türker ${ }^{3}$

${ }^{1}$ Department of Biology, A.K. Education Faculty,

Necmettin Erbakan University, 42090, Konya, Turkey

${ }^{2}$ Department of Fisheries, Bandirma Sheep

Research Institute, 10200, Balıkesir, Turkey

${ }^{3}$ Department of Biology, Science Faculty, Balikesir

University, 10300, Balikesir, Turkey
Clavella alata Brian, 1909 (Siphonostomatoida; Lernaeopodidae) was reported on Phycis blennoides (Brünnich, 1768) in Turkey. Phycis blennoides (Gadiformes; Phycidae) is a new host for Clavella alata in Turkey. Also, some of the morphological characteristics of this parasitic copepod are given in photographs and drawings.

Keywords: Clavella, Phycis, parasitic copepod, Turkey

\section{INTRODUCTION}

Lernaeopodidae is a large and diverse family of highly specialized parasitic copepods, currently comprising 48 genera (Boxshall, Halsey, 2004). Lernaeopodidae comprise more than 260 species which mainly parasitize both elasmobranchs and teleosts. The female frequently presents a characteristic attachment organ, the bulla, which is unique among parasitic copepods and is held by the second maxillae. The small male lives in temporary association, often on the body of its partner (Benkirane et al., 1999; WoRMS, 2016).

Raibaut et al. (1998) reviewed the occurence of 226 parasitic copepod species distributed in 88 genera and 20 families from fishes of the Mediterranean Sea.

This paper presents a new host for Clavella alata from Turkey.

\footnotetext{
* Corresponding author. E-mail: alasali@hotmail.com
}

\section{MATERIALS AND METHODS}

Seventy of Phycis blennoides (Brünnich, 1768) (Gadiformes; Phycidae) were collected by local gears from North Aegean Sea of Turkey in 2014. The parasites collected were fixed in $70 \%$ ethanol. Some of specimens were later cleared in lactic acid before dissection of the appendages of copepods. The drawings of the appendages were carried out with the aid of camera lucida (Olympus BH-DA). The photos were taken with the aid of Canon EOS $1100 \mathrm{D}$ connected to a microscope. Measurements were taken in millimetres $(\mathrm{mm})$, with a micrometric programme (Pro-way). Scientific names and the synonyms for the parasite and the host were checked with WoRMS (2016), Froese and Pauly Editors (2016). Kabata (1979) was consulted for terminology. Clavella alata (MNHNIU-2013-18740) was deposited in the collections of the Museum National d'Histoire Naturelle (MNHN), Paris, France. 


\section{RESULTS}

Clavella alata Brian, 1909 (Copepoda; Siphonostomatoida; Lernaeopodidae)

\section{(Figures 1-3)}

All parasites were firmly attached to the gill filaments. The prevalence of parasite was $42.8 \%$. The mean intensity of the parasite was 1.3.
The total number of parasites was 40. Body length varies from 3 to $4.5 \mathrm{~mm}$. The cephalothorax is subcylindrical, longer than the trunk and the second maxilla. The trunk is ovate or pyriform, with truncated posterior margin. The length of the second maxilla seldom reaches half length of the trunk; it is slender and tapering. The first maxilla (Fig. 2b, 3d) exopod from
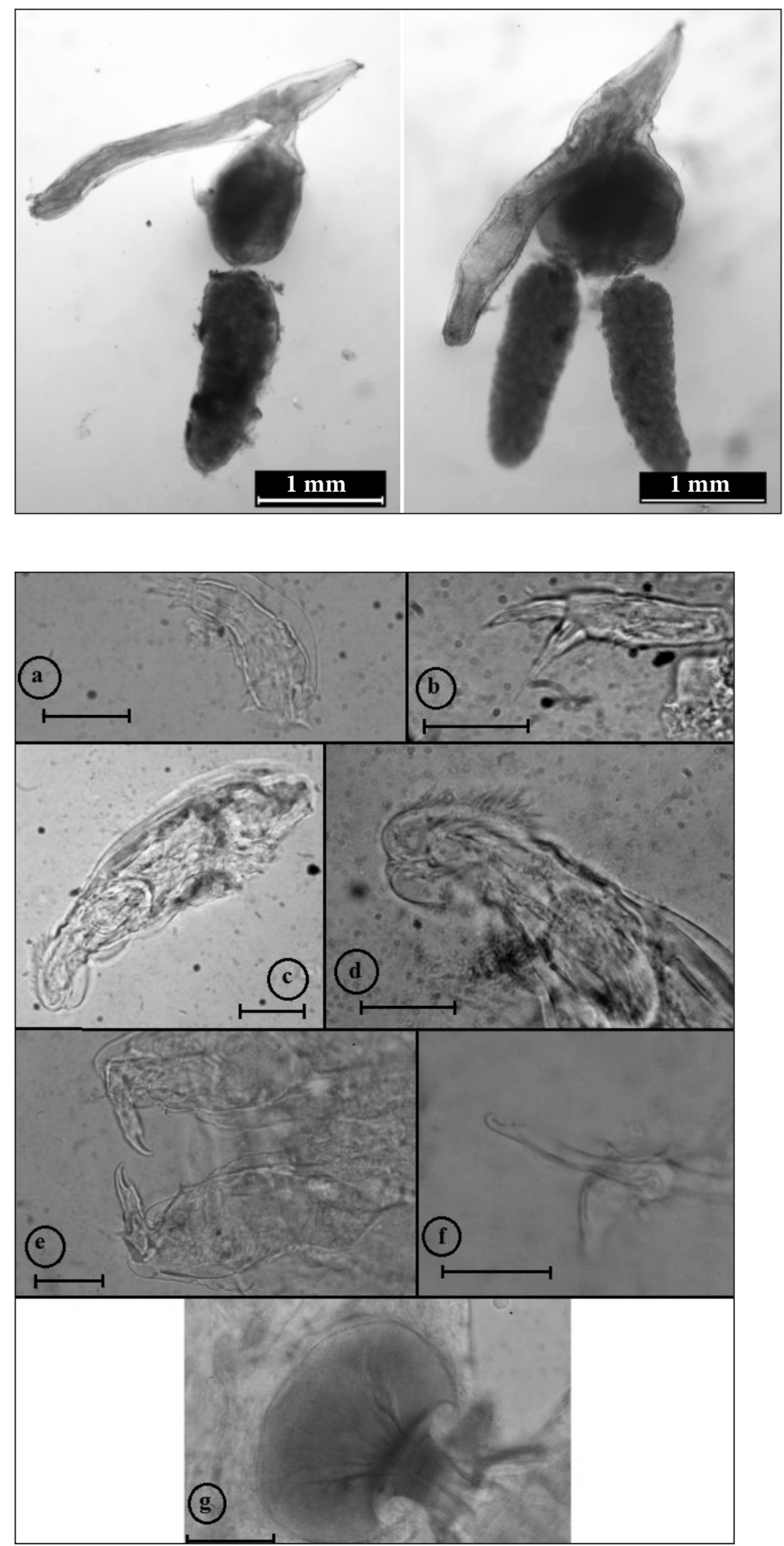

Fig. 1. Clavella alata 9 . habitus, lateral, front (Scale $1 \mathrm{~mm}$ )
Fig. 2. Clavella alata ${ }$. a - the first antenna $(0.03 \mathrm{~mm}), \mathrm{b}-$ the first maxilla $(0.025 \mathrm{~mm}), \mathrm{c}-$ the second antenna $(0.07 \mathrm{~mm}), \mathrm{d}-$ the exopod of the second antenna $(0.07 \mathrm{~mm})$, e - the maxilliped $(0.025 \mathrm{~mm}), \mathrm{f}-$ the mandible $(0.02 \mathrm{~mm})$, $\mathrm{g}$ - bulla $(0.07 \mathrm{~mm})$ 


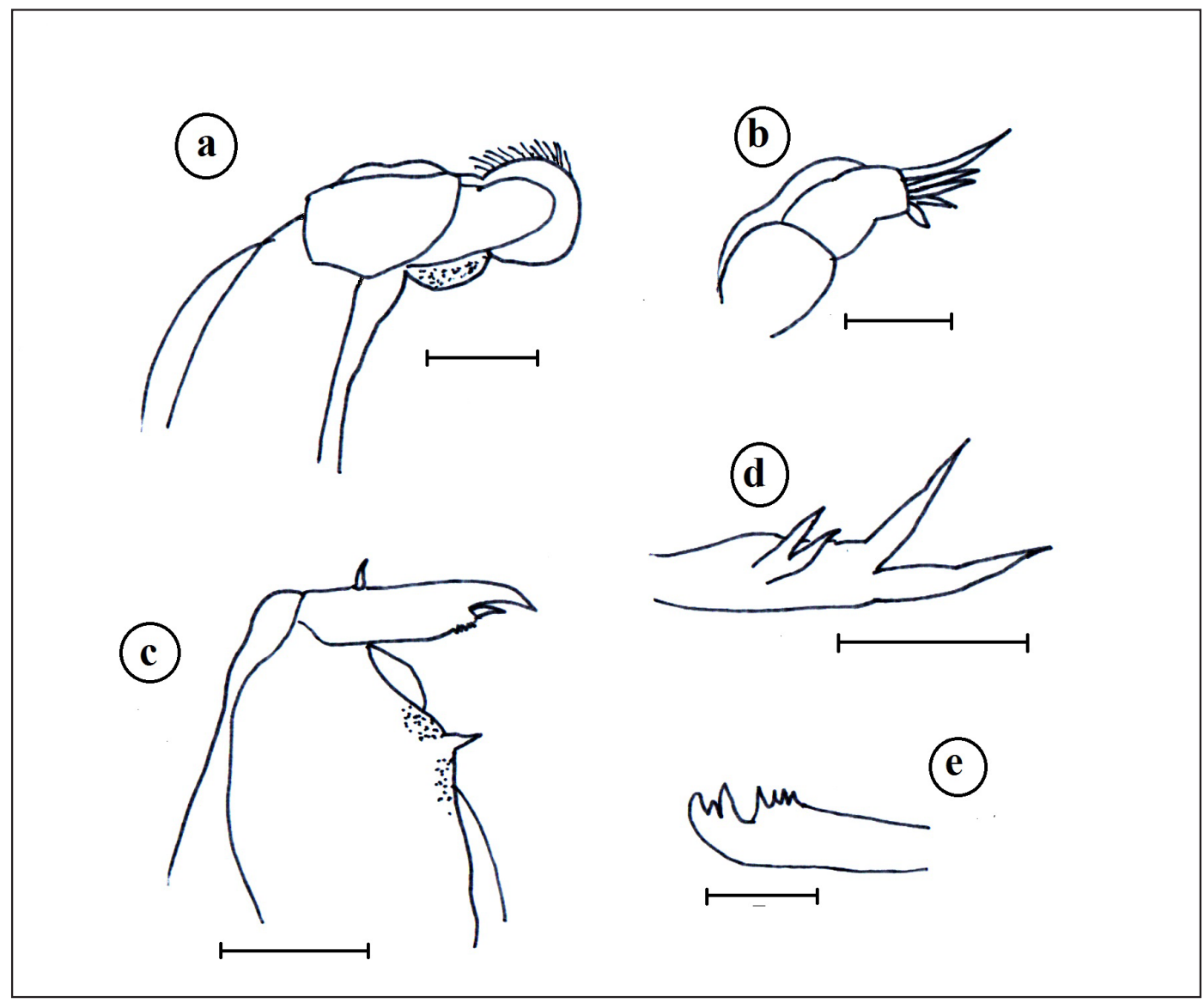

Fig. 3. Clavella alata 9 . a - the second antenna $(0.07 \mathrm{~mm}), \mathrm{b}-$ the first antenna $(0.03 \mathrm{~mm})$, $\mathrm{c}$ - the maxilliped $(0.5 \mathrm{~mm}), \mathrm{d}$ - the first maxilla $(0.025 \mathrm{~mm}), \mathrm{e}-$ the mandible $(0.02 \mathrm{~mm})$

ventral to lateral armed with two short subapical setae; the endopod with two digitiform papillae, each bears apical long seta. The first antenna (Fig. 2a, 3b) is distinctly two-segmented. Distal armature includes 5 visible elements: one tubercule, one short seta, two equal setae and one long slender seta. The second antenna (Fig. 2c, 3a) with sympod-endopod long axis; the exopod is displaced from the main axis of appendage, relatively smaller than endopod, one-segmented and armed with long denticles; the endopod is covered with fine denticles in medial. The maxilliped has a robust corpus, myxa with a denticulated patch and one short seta at about mid-length; the subchela is cylindrical, with basal seta; a sturdy barb reaches close to the tip of the claw; the claw is sturdy (Fig. 2e, 3c). The mandible has the dental formula P1S1P1...B4 (Fig. 2f, 3e). The bulla is mushroom-shaped (Fig. 2g).

\section{DISCUSSION}

Clavella alata has been reported from the North Sea and British waters, from the southern coast of Spain, the Algerian coast, and the Mediterranean. It was reported only on Phycis genus such as Phycis blennoides (Brian, 1906; Scott, Scott, 1913; Papoutsoglou, 1976; Kabata, 1979; Raibaut et al., 1998) and Phycis phycis (NunesRuivo, 1953; Kabata, 1963; Ramdane, Trilles, 2010).

The hosts parasitising with Clavella alata were examined according to family characteristics: two host species belong to Phycidae. The hosts parasitising with Clavella alata were examined according to habitat selections; two host fish species are benthopelagic. The hosts parasitising with Clavella alata were examined according to their feeding habits; two host fish species are carnivorous. 
Nine species of the family Lernaeopodidae are reported from marine habitats in Turkey (Alaş et al., 2015): Clavellotis fallax (Heller, 1865), Clavellisa scombri (Kurz, 1877), Clavellotis strumosa (Brian, 1906), Lernaeopoda galei Kroyer, 1837, Thysanote impudica (von Nordmann, 1832), Parabrachiella bispinosa (von Nordmann, 1832), Parabrachiella exigua (Brian, 1906), Clavella alata Brian, 1909, Parabrachiella hostilis (Heller, 1868).

Clavella alata was presented from Turkey by Öktener et al. (2010), so it was published only as an abstract. Thus this is the second report on a new host in Turkey. The drawings of general morphology and dissected extremities (first maxilla, first antenna, second antenna, maxilliped, mandible) of Clavella alata in this study were very similiar to the findings of Brian, 1906; Scott, Scott, 1913; Wilson, 1915; Nunes-Ruivo, 1953; Kabata, 1963; Kabata, 1979; Ho, 1993.

This study contributes to research into the distribution and host preference of Clavella alata in Turkey.

Received 3 August 2016 Accepted 20 September 2016

\section{References}

1. Öktener A, Alaş A, Türker D. First record of Parabrachiella hostilis (Heller, 1868) (Copepoda: Lernaeopodidae) from Umbrina cirrosa (Linnaeus, 1758) (Pisces: Sciaenidae) in Turkey. Bull Eur Ass Fish Pathol. 2015; 35(4): 131-7.

2. Benkirane OF, Coste F, Raibaut A. On the morphological variability of the attachment organ of Lernaeopodidae (Copepoda: Siphonostomatoida). Folia Parasitol. 1999; 46: 67-75.

3. Boxshall GA, Halsey SA. An introduction to copepod diversity. London: The Ray Society; 2004. 1-2: 966 p.

4. Brian A. Copepodi parassiti dei Pesci d'Italia. Genova: Stab. Tipo-Litografico R. Istituto Sordomuti; 1906. 187 p. Italian.
5. Froese R, Paul D. Editors [Internet]. FishBase. World Wide Web electronic publication. www. fishbase.org, version (01/2016).

6. Ho JS. New Species of Clavella (Copepoda: Lernaeopodidae) Parasitic on Japanese Rattails (Pisces: Macrouridae). Publ Seto Mar Biol Lab. 1993; 36(3): 107-18.

7. Kabata Z. The Second Antenna in the Taxonomy of Clavellinae (Copepoda, Lernaeopodidae). Crustaceana. 1963; 6(1): 5-14.

8. Kabata Z. Parasitic Copepoda of British Fishes. London: Ray Society Publications, The British Museum; 1979. 152, 468 p.

9. Nunes-Ruivo L. Copepodes parasites des poissons. Resultats des campagnes du "Pr. Lacaze Duthiers". Vie et Milieu. 1953; 3: 115-38.

10. Öktener A, Torcu Koç H, Alaş A, Erdoğan Z. Three Copepods from Marine Fishes of Aegean Sea Coasts of Turkey. 9th International Congress on Biology of Fish; 2010 July 5-9; Barcelona, Spain.

11. Papoutsoglou SE. Metazoan Parasites of Fished from Saronicos Gulf Athens, Greece. Thalassographica. 1976; 1(1): 69-102.

12. Raibaut A, Combes C, Benoit F. Analysis of the parasitic copepod species richness among Mediterranean fish. J Marin System. 1998; 15: 185-206.

13. Ramdane Z, Trilles JP. New Algerian parasitic copepods. Bull Eur Ass Fish Pathol. 2010; 30(2): 41-7.

14. Scott T, Scott A. British Parasitic Copepoda. London: Ray Society; 1913. 1-2, 252 p.

15. Wilson CB. North American Parasitic Copepods Belonging to the Lernaeopodidae, with a revision of the entire Family. Proceed US Nat Mus. 1915; 47 (2063): 565-729.

16. WoRMS [Internet]. World Register of Marine Species. Available from http://www.marinespecies.org at VLIZ. Accessed 28.12.2015. 
Ali Alaş, Ahmet Öktener, Dilek Türker

NAUJAS CLAVELLA ALATA BRIAN, 1909 (SIPHONOSTOMATOIDA, LERNAEOPODIDAE) ŠEIMININKAS TURKIJOS JŪROSE

\section{Santrauka}

Lernaeopodidae yra didelè ir įvairi parazitinių irklakojų šeima, kurią šiuo metu sudaro 48 gentys ir daugiau nei 260 rūšių. Dažniausiai šie irklakojai parazituoja selachijas (Elasmobranchii) ir kaulingąsias žuvis (Teleostei). Clavella alata Brian, 1909 rūšis aptinkama Šiaurès jūroje, Didžiosios Britanijos vandenyse, ị pietus iki Ispanijos ir Alžyro krantų bei Viduržemio jūroje. Šios rūšies šeimininku buvo žinoma tik siūlapelekių vẻgèlių (Phycidae) šeima, pavyzdžiui, Phycis blennoides ir Phycis phycis. Šiame straipsnyje pristatomas Turkijoje aptiktas naujas Clavella alata rūšies šeimininkas. Tyrimo metu $2014 \mathrm{~m}$. Šiaurès Egèjo jūroje, Turkijoje, buvo sugauta 70 Phycis blennoides (Brünnich, 1768) (Gadiformes; Phycidae) rūšies vegèlių. Iš viso aptikta 40 Clavella alata rūšies parazitų. Nustatytas paplitimas ir vidutinis intensyvumas sudare atitinkamai $42,8 \%$ ir 1,3 . Tyrimo rezultatai patvirtina Clavella alata rūšies pasiskirstymą ir šeimininko pirmenybę Turkijoje.

Raktažodžiai: Clavella, Phycidae, parazitinis, irklakojai, Turkija 